\title{
Twentieth-century trends in the thermal growing season in the Greater Baltic Area
}

\author{
Hans W. Linderholm • Alexander Walther • \\ Deliang Chen
}

Received: 13 October 2005 / Accepted: 27 July 2007 / Published online: 4 October 2007

(C) Springer Science + Business Media B.V. 2007

\begin{abstract}
Phenological data have shown an increase of ca. 10 days in European growing season length in the latter part of the twentieth century. In general, these changes have been associated with global warming. Here we present a study of thermal growing season (GS) trends in the Greater Baltic Area, northern Europe. Yearly dates for the start, end and length of the GS were computed for 49 stations in the studied area, using daily mean temperature measurements. Trends and tendencies of the GS parameters were analysed within the twentieth century. We also examined GS trends in long records (starting before 1850) from the region. The results show a general increase of the length of the GS of ca one week since 1951 in the area, where the most considerable change has occurred in spring (starting $\sim 6$ days earlier). The largest increases were found at stations adjacent to the Baltic Sea and North Sea, where some Danish stations showed significant increasing trends in the length of the GS of more than 20 days. The only tendency for a shorter GS was found in Archangelsk, north western Russia. The three longest records displayed large inter-annual and decadal variability, with tendencies for increased frequencies of longer growing seasons since the 1950 s.
\end{abstract}

\section{Introduction}

In the past decade, a growing number of studies have reported on a late-twentieth century lengthening of the growing season for most of the Northern Hemisphere, associated with increasing temperatures (e.g., Frich et al. 2002; Parmesan and Yohe 2003; Root et al. 2003). The relationship between climate and growing season (GS) parameters (start, end and length), makes GS variability an important indicator of climate change. Evidence for lengthening of the growing season in the late twentieth century has come from satellite data, phenological and meteorological observations. Keeling et al. (1996) showed an association between surface air temperatures and variations in the timing and amplitude of the seasonal

H. W. Linderholm $(\square) \cdot$ A. Walther $\cdot$ D. Chen

Regional Climate Group, Earth Sciences Centre, Göteborg University, 40530 Göteborg, Sweden e-mail: hansl@gvc.gu.se

H. W. Linderholm • D. Chen

Laboratory for Climate Studies, National Climate Center, China Meteorological Administration, 46 Zhongguancun Nandajie, Haidian, Beijing 100081, China 
cycle of atmospheric $\mathrm{CO}_{2}$. An increase of the annual amplitude of the seasonal $\mathrm{CO}_{2}$ cycle by $40 \%$ in the Arctic (20\% in Hawaii) since the early 1960 s, where warmer temperatures promote increases in plant growth in summer and/or respiration in winter, was linked to a lengthening of the GS by about 7 days. Furthermore, the photosynthetic activity of terrestrial vegetation, as seen in satellite data, increased from 1981 to 1991 which is also associated with a lengthening of the active growing season (Myneni et al. 1997).

A large number of phenological studies have reported on recent changes in timing of GS start and end, resulting in an extension of the GS. Phenology studies plant and animal life stages driven by environmental factors (Schwartz 1999). Species whose phenophases (e.g. flowering, leafing, breeding, leaf fall etc.) are linked to temperatures, will respond to changing temperatures with shifts in the phenophases. Phenological data have indicated shifts to earlier start of the GS in the latter half of the twentieth century, which has been coupled to warmer winters associated with the variation in the North Atlantic Oscillation, NAO (Chmielewski and Rötzer 2001; Ahas et al. 2002; D’Odorico et al. 2002; Scheifinger et al. 2002; Menzel 2003; Ahas et al. 2004), warming in spring (Cayan et al. 2001; Chmielewski and Rötzer 2002; Chmielewski et al. 2004) and increases in minimum temperatures or longer frost-free period (Abu-Asab et al. 2001; Scheifinger et al. 2003). Common results for most recent phenological studies are an extended GS, which is mainly caused by earlier onset of the GS start in spring (Ahas 1999; Menzel and Fabian 1999; Menzel 2000; Menzel et al. 2001; Ahas et al. 2002; Peñuelas et al. 2002). Similar findings, i.e. an extended GS during the late twentieth century, have also been observed when the climatological GS is studied for large parts of the Northern Hemisphere (Frich et al. 2002). The reported increases in growing season length (GSL) are in a range of ca. 1 to 3 weeks (Skaggs and Baker 1985; Carter 1998; Hasenauer et al. 1999; Robeson 2002; Schwartz and Chen 2002; Menzel et al. 2003). However, Kozlov and Berlina (2002) found a shift to later snow-melt by 16 days in spring in the northern Russian taiga for the period 1930 to 1998 . In addition, there was a shift of 13 days towards earlier dates of permanent snow in the same area during that period.

Future climate change is projected to increase the length of the growing season (e.g. IPCC 2001). An increase in GSL, together with a warmer climate during GS, may advance the potential for crop production at high northern latitudes and increase the potential number of harvests and hence seasonal yields for perennial forage crops (ACIA 2004). Effects at high northern latitudes could be elevated tree line, improved forest productivity and favourable conditions for growing more southerly fruits (e.g. Hasenauer et al. 1999; Wielgolaski 2003). However, the accelerated rates of change seen in the past three decades indicate that in a near future we will see large changes in ecosystems which may have negative effects on ecosystems, such as extension of species' range boundaries by establishment of new local populations causing extinction of former populations, and progressive decoupling of species interaction (e.g. plants and pollinators) because of out-ofphase phenology (e.g. Hughes 2000; Peñuelas and Filella 2001). Barford et al. (2001) found that seasonal and annual fluctuations of the uptake of $\mathrm{CO}_{2}$ in a northern hardwood forest were regulated by weather and seasonal climate (e.g. variations in growing-season length). Consequently, persistent increases in GSL may lead to long-term increases in carbon storage (White et al. 1999).

In this paper we analyse twentieth century trends in the GS from a network of stations in "the Greater Baltic Area" (GBA, Walther and Linderholm 2006). This region, which largely belongs to the boreal region, may be especially sensitive to changes in the growing season. Recent climate warming in the boreal region has increased the probability of occurrence of critical temperature thresholds for the production of existing agricultural crops. Possible 
future climate warming would increase the land area on which crops could be produced successfully, and the variety of agricultural crops that could be grown (Juday et al. 2005).

\section{Data}

We analysed temperature records from 48 stations where daily observations were available. The station data was obtained from datasets collected, processed and made available within two large projects: the European Climate Assessment and Dataset (ECA\&D, Klein Tank et al. 2002, http://eca.knmi.nl) and European and North Atlantic daily to Multidecadal climate variability (EMULATE, http:/www.cru.uea.ac.uk/cru/projects/emulate/). The data will be briefly described here, for a detailed description we refer to Moberg et al. (2006). The station network is quite evenly spread over the GBA (Fig. 1), but station density is low in the central and northern parts of Fennoscandia (especially Finland). The station records have been through basic quality control (QC, see Moberg et al. 2006), but no homogeneity tests have been applied, except for two Swedish stations (Bergström and Moberg 2002; Moberg et al. 2002). Since unhomogenized records may contain artificial changes, some of the trend values presented here should be viewed upon with some caution. Only 21 of 48 records start 1901 or earlier. The long (starting at least 1901) and very long records (starting before 1850) are concentrated in the southern part of the GBA. In order to increase the station density and the possibility to obtain spatial patterns from a higher number of records, relatively shorter records (starting after 1901) were included as well. Information about the start and end years of the station records are shown in Table 1.

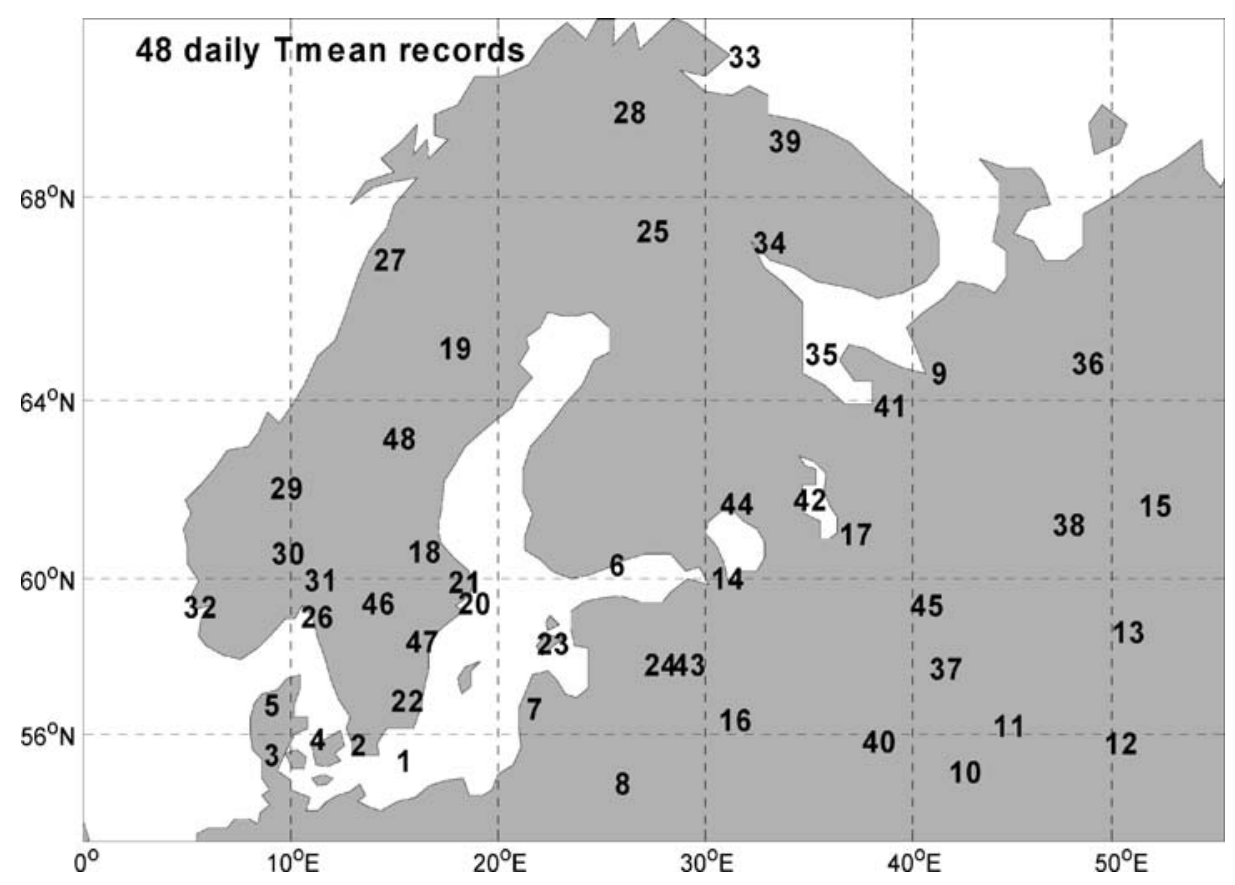

Fig. 1 Locations of the $48 T_{\text {mean }}$ stations in the Greater Baltic Area used in the study. See Table 1 for station data 
Table 1 Station data for the 48 station used in the analyses

\begin{tabular}{|c|c|c|c|c|c|c|c|c|}
\hline & Lat. $\left({ }^{\circ} \mathrm{N}\right)$ & Lon. $\left({ }^{\circ} \mathrm{E}\right)$ & Elev. (m) & Station & country & start & end & Ref. $^{\mathrm{a}}$ \\
\hline 1 & 55.3 & 14.8 & 12 & Hammer-Odde-Fyr & DK & 1874 & 2004 & (1) \\
\hline 2 & 55.7 & 12.5 & 9 & Koebenhavn & DK & 1874 & 2003 & (1) \\
\hline 3 & 55.5 & 8.4 & 4 & Nordby & DK & 1874 & 2003 & (1) \\
\hline 4 & 55.9 & 10.6 & 11 & Tranebjerg & DK & 1873 & 2003 & (1) \\
\hline 5 & 56.8 & 8.3 & 18 & Vestervig & DK & 1874 & 2003 & (1) \\
\hline 6 & 60.3 & 25.0 & 51 & Helsinki & FIN & 1828 & 2001 & (4) \\
\hline 7 & 56.7 & 21.0 & 4 & Liepaja & LV & 1881 & 1989 & $(2)$ \\
\hline 8 & 54.6 & 25.3 & 162 & Vilnjus & LT & 1881 & 1989 & $(1,2)$ \\
\hline 19 & 64.6 & 40.5 & 8 & Archangelsk & RUS & 1881 & 1999 & (1) \\
\hline 10 & 55.0 & 41.8 & 132 & Elatma & RUS & 1886 & 1999 & (1) \\
\hline 11 & 56.2 & 43.8 & 161 & Gorkij & RUS & 1881 & 1989 & (2) \\
\hline 12 & 55.8 & 49.2 & 116 & Kazan & RUS & 1881 & 1989 & (2) \\
\hline 13 & 58.7 & 49.6 & 165 & Kirov & RUS & 1881 & 1989 & (2) \\
\hline 14 & 60.0 & 30.3 & 4 & St-Petersburg & RUS & 1743 & 1999 & (3) \\
\hline 15 & 61.7 & 50.9 & 96 & Syktyvar & RUS & 1888 & 1999 & (1) \\
\hline 16 & 56.4 & 30.6 & 98 & Velikie-Luki & RUS & 1881 & 1999 & (1) \\
\hline 17 & 61.0 & 36.5 & 55 & Vytegra & RUS & 1881 & 1999 & (1) \\
\hline 18 & 60.6 & 15.7 & 157 & Falun & $\mathrm{S}$ & 1860 & 2002 & \\
\hline 19 & 65.1 & 17.2 & 325 & Stensele & $\mathrm{S}$ & 1918 & 2003 & \\
\hline 20 & 59.4 & 18.1 & 44 & Stockholm & $\mathrm{S}$ & 1756 & 2003 & (5) \\
\hline 21 & 59.9 & 17.6 & 13 & Uppsala & $\mathrm{S}$ & 1722 & 2001 & (5) \\
\hline 22 & 56.9 & 14.8 & 166 & Vaexjoe & $\mathrm{S}$ & 1918 & 2003 & \\
\hline 23 & 58.4 & 21.8 & 6 & Vilsandi & EST & 1920 & 2004 & (1) \\
\hline 24 & 57.9 & 27.0 & 82 & Voru & EST & 1923 & 2001 & (1) \\
\hline 25 & 62.4 & 25.7 & 137 & Jyvaskyla & FIN & 1951 & 2004 & (1) \\
\hline 26 & 59.0 & 10.5 & 6 & Faerder-Fyr & $\mathrm{N}$ & 1951 & 2004 & (1) \\
\hline 27 & 66.8 & 14.0 & 39 & Glomfjord & $\mathrm{N}$ & 1943 & 2001 & (1) \\
\hline 28 & 69.5 & 25.5 & 129 & Karasjok & $\mathrm{N}$ & 1943 & 2001 & (1) \\
\hline 29 & 62.1 & 9.1 & 626 & Kjoeremsgrende & $\mathrm{N}$ & 1954 & 2004 & (1) \\
\hline 30 & 60.6 & 9.1 & 167 & Nesbyen-Skoglund & $\mathrm{N}$ & 1943 & 2004 & (1) \\
\hline 31 & 60.0 & 10.7 & 94 & Oslo-Blindern & $\mathrm{N}$ & 1938 & 2004 & (1) \\
\hline 32 & 59.3 & 4.9 & 55 & Utsira-Fyr & $\mathrm{N}$ & 1943 & 2003 & (1) \\
\hline 33 & 70.4 & 31.1 & 14 & Vardoe & $\mathrm{N}$ & 1951 & 2004 & (1) \\
\hline 34 & 67.2 & 32.4 & 25 & Kandalaksa & RUS & 1912 & 2004 & (1) \\
\hline 35 & 65.0 & 34.8 & 8 & Kem & RUS & 1916 & 2000 & (1) \\
\hline 36 & 64.8 & 47.7 & 64 & Kojnas & RUS & 1912 & 1999 & (1) \\
\hline 37 & 57.7 & 40.8 & 126 & Kostroma & RUS & 1925 & 1999 & (1) \\
\hline 38 & 61.2 & 46.7 & 56 & Kotlas & RUS & 1936 & 1999 & (1) \\
\hline 39 & 69.0 & 33.1 & 51 & Moermansk & RUS & 1936 & 1999 & (1) \\
\hline 40 & 55.8 & 37.6 & 156 & Moskow & RUS & 1948 & 1999 & (1) \\
\hline 41 & 63.9 & 38.1 & 13 & Onega & RUS & 1936 & 2004 & (1) \\
\hline 42 & 61.8 & 34.3 & 110 & Petrozawodsk & RUS & 1936 & 1999 & (1) \\
\hline 43 & 57.8 & 28.4 & 45 & Pskow & RUS & 1936 & 2004 & (1) \\
\hline 44 & 61.7 & 30.7 & 19 & Sortavala & RUS & 1945 & 2004 & (1) \\
\hline 45 & 59.3 & 39.9 & 130 & Wologda & RUS & 1938 & 1999 & (1) \\
\hline 46 & 59.4 & 13.5 & 46 & Karlstad & $\mathrm{S}$ & 1918 & 2001 & (1) \\
\hline 47 & 58.4 & 15.5 & 93 & Linkoeping & $\mathrm{S}$ & 1931 & 2004 & (1) \\
\hline 48 & 63.2 & 14.5 & 376 & Oestersund & $\mathrm{S}$ & 1918 & 2004 & (1) \\
\hline
\end{tabular}

a References: (1) European Climate Assessment \& Dataset (ECA\&D): http://eca.knmi.nl; (2) Carbon Dioxide Information Analysis Centre (CDIAC): http://cdiac.ornl.gov/ftp/ndp040; (3) Jones and Lister 2002; (4) Heino 1994; (5) Moberg et al. 2002 


\section{Methods}

The climatological growing season can be defined as the entire period in which growth can theoretically take place; it is not the period of actual growth. There are a number of ways to define start, end and length of the growing season. One definition of GSL that has been used in USA is the period between the date of the last spring frost and first autumn frost (e.g. Skaggs and Baker 1985; Robeson 2002), where the frost may be determined by thresholds of daily minimum temperatures. Other investigations have used threshold temperatures in a predefined number of days to start and end the growing season. In Bootsma's (1994) definition of the growing season in Canada, it starts at the date when the 5-day weighted mean temperatures reached and stayed above $5.5^{\circ} \mathrm{C}$ and ends when the weighted temperatures fall below $5.5^{\circ} \mathrm{C}$. Jones and Briffa (1995) defined the start of the growing season in Russia as the fourth day of the first sequence of 4 consecutive days with temperatures above the $5^{\circ} \mathrm{C}$ threshold, and the end was defined as the last day of the last 4-day sequence above the $5^{\circ} \mathrm{C}$. Later, Jones et al. (2002) revised the definition, so that the growing season start/end was defined as the first/last five-day period occurring after/before the last/first frost of the winter season. Frich et al. (2002), in a global study, used the period when daily temperatures remain above $5^{\circ} \mathrm{C}$ for $>5$ days and below $5^{\circ} \mathrm{C}$ for $>5$ days. Carter (1998) defined the start of the growing season as $>5^{\circ} \mathrm{C}$ for $\geq 5$ days and the end when the 10-day running mean of mean daily temperatures falls below $5^{\circ} \mathrm{C}$. In a comparison of different indices for the start and end of the growing season in the Greater Baltic Area (GBA), Walther and Linderholm (2006) noted that disregarding the frost criteria might lead to false starts and ends of the growing season. In this study we use the definitions of GS parameters that were suggested for the GBA, where the start day of the growing season is defined as the last day of the first six-day spell with daily $T_{\text {mean }}$ above $5^{\circ} \mathrm{C}$ after the last winter/spring frost (based on $T_{\text {mean }}$ ). The end-day of the growing season is defined as the first day of the first 10 -day period with a mean below $5^{\circ} \mathrm{C}$. Finally, the GSL is the number of days between the particular start- and end-day. Using the $5^{\circ} \mathrm{C}$ threshold in northern Europe can be justified, since the growing season is largely temperature limited. The physiological significance of this period naturally differs among plant types, but it can be assumed to be relevant to perennial plants that are exposed to weather throughout the year, e.g. trees and shrubs (Carter 1998).

Using these definitions we produced time series of the start, end and length of the GS for each station included in the data set. Trend analyses were made in three time periods: 19011950, 1951-2000 and 1901-2000. The periods were chosen for several reasons. The division of the 20th century provides a comparison of the sub-periods. 50 years provide sufficient data for the trend method to work. Analyses of the 100-year period provide longterm results. Besides, the 50 and 100 year periods are commonly used in climate change studies. Two main problems are data availability and temporal coverage of the respective time-series. In order to use the series available as much and efficient as possible, we also computed the linear trends for the entire record of each station. In this way we also include results from three very long time-series starting in the 1700s. An overall missing value criteria was applied when computing the growing season parameters. Up to 12 missing values in the particular annual $T_{\text {mean }}$ series were allowed (=1 missing value/month). If a series contains more missing values, the growing season parameters were set missing values as well. The temperature series generally contained either high or very low rates of missing values. In order to be able to include also series with high missing value rates, we looked at the distribution of these within the series. In this context the growing season parameters was computed, if the dates of the missing values clearly did not affect the start or the end of the 
particular growing season (e.g. missing values before the last spring frost or after the first 10 -day mean period below $5^{\circ} \mathrm{C}$ ). For computing the linear trends up to $5 \%$ missing growing season parameters in the particular period to be analysed were allowed ( $=5$ years missing/ 100 years). The growing season time-series was analysed for linear trends using the ordinary least squares method (OLS). The significance of the trends was tested using the Mann-Kendall test (Yue et al. 2002). Trends were defined to be significant at $p<0.05$ and highly significant with $p<0.01$.

\section{Twentieth-century trends and tendencies}

Due to the large variation in station record lengths and occasionally large numbers of missing values, the number of stations in each period analyzed was lower than expected, especially in the periods starting before 1951; 1901-1950: 11 stations, 1951-2000: 37 stations and 1901-2000: 11 stations. The results of the trend analyses of start, end and length of the growing season are shown in Fig. 2 and Table 2.
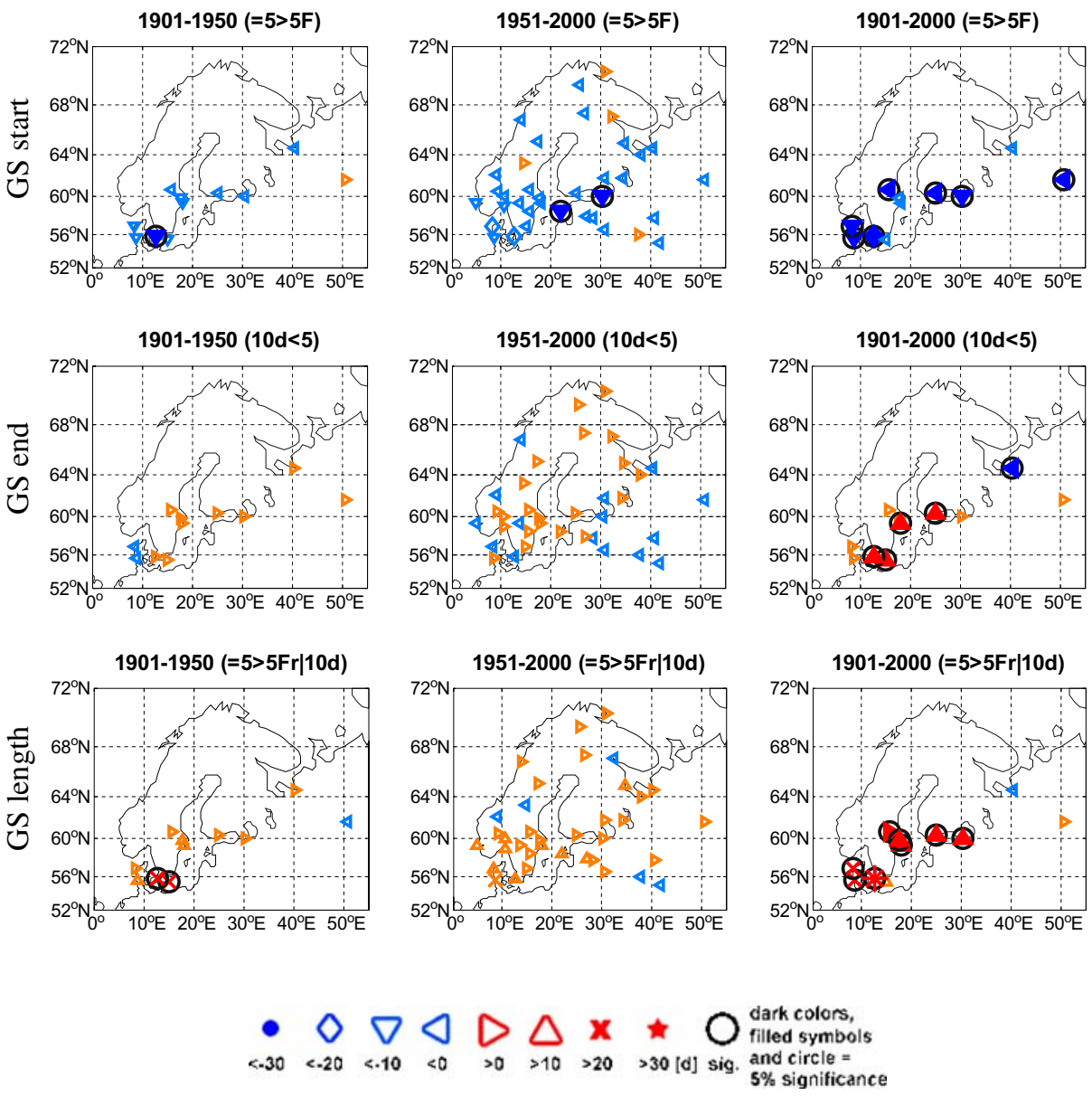

Fig. 2 Trends in start, end and length of the thermal growing season for three periods in the twentieth century (see text for explanation of definitions) 
Table 2 Linear trends in growing season parameters for three periods in the twentieth century

\begin{tabular}{|c|c|c|c|c|c|c|c|c|c|c|c|}
\hline & & & \multicolumn{3}{|c|}{$1901-1950$} & \multicolumn{3}{|c|}{$1951-2000$} & \multicolumn{3}{|c|}{ 1901-2000 } \\
\hline & & & Start & End & Length & Start & End & Length & Start & End & Length \\
\hline 1 & Hammer-Odde-Fyr & DK & -11.1 & 9.0 & 20.2 & - & - & - & -0.3 & 10.2 & 10.5 \\
\hline 2 & Koebenhavn & DK & -19.2 & 5.7 & 24.9 & $-24.5^{\mathrm{a}}$ & $-4.0^{\mathrm{a}}$ & $17.2^{\mathrm{a}}$ & -22.8 & 12.6 & 33.5 \\
\hline 3 & Nordby & DK & -13.9 & -0.8 & 13.1 & -18.1 & 4.0 & 22.5 & -18.2 & 8.3 & 26.5 \\
\hline 5 & Vestervig & DK & -10.9 & -7.3 & 3.6 & -22.1 & -3.3 & 18.8 & -16.5 & 6.1 & 22.6 \\
\hline 6 & Helsinki & FIN & -6.6 & 0.8 & 7.3 & -1.0 & 2.8 & 3.8 & -9.5 & 10.5 & 19.9 \\
\hline 9 & Archangelsk & RUS & -1.1 & 3.8 & 4.9 & $-4.5^{\mathrm{a}}$ & $-4.0^{\mathrm{a}}$ & $0.5^{\mathrm{a}}$ & -3.6 & -7.1 & -3.6 \\
\hline 10 & Elatma & RUS & - & - & - & -0.9 & -6.7 & -5.8 & - & - & - \\
\hline 14 & St-Petersburg & RUS & -2.9 & 2.0 & 4.9 & -10.7 & -3.1 & 7.6 & -10.6 & 3.5 & 14.2 \\
\hline 15 & Syktyvar & RUS & 5.7 & 3.0 & -2.7 & $-5.5^{\mathrm{a}}$ & $-1.1^{\mathrm{a}}$ & $4.3^{\mathrm{a}}$ & -9.1 & 0.2 & 9.2 \\
\hline 16 & Velikie-Luki & RUS & - & - & - & $-5.1^{\mathrm{b}}$ & $-3.3^{b}$ & $1.8^{\mathrm{b}}$ & - & - & - \\
\hline 18 & Falun & $\mathrm{S}$ & -6.7 & 2.9 & 9.6 & -2.4 & 5.5 & 7.9 & -8.6 & 1.1 & 9.7 \\
\hline 19 & Stensele & $\mathrm{S}$ & - & - & - & -1.4 & 1.0 & 2.3 & - & - & - \\
\hline 20 & Stockholm & $\mathrm{S}$ & -10.5 & 5.1 & 15.6 & -5.2 & 5.5 & 10.6 & -6.2 & 11.7 & 17.9 \\
\hline 21 & Uppsala & $\mathrm{S}$ & -11.0 & 2.9 & 13.9 & -4.7 & 1.4 & 6.1 & -7.8 & 7.6 & 15.4 \\
\hline 22 & Vaexjoe & $\mathrm{S}$ & - & - & - & -4.8 & 1.3 & 6.2 & - & - & - \\
\hline 23 & Vilsandi & EST & - & - & - & -10.8 & 1.4 & 12.2 & - & - & - \\
\hline 24 & Voru & EST & - & - & - & -8.7 & 2.8 & 11.5 & - & - & - \\
\hline 25 & Jyvaskyla & FIN & - & - & - & -1.5 & 3.7 & 5.2 & - & - & - \\
\hline 26 & Faerder-Fyr & $\mathrm{N}$ & - & - & - & -16.6 & 3.5 & 20.0 & - & - & - \\
\hline 27 & Glomfjord & $\mathrm{N}$ & - & - & - & -2.9 & -1.1 & 1.8 & - & - & - \\
\hline 28 & Karasjok & $\mathrm{N}$ & - & - & - & -7.1 & 0.4 & 7.5 & - & - & - \\
\hline 29 & Kjoeremsgrende & $\mathrm{N}$ & - & - & - & $-3.0^{\mathrm{a}, \mathrm{b}}$ & $-3.0^{\mathrm{a}, \mathrm{b}}$ & $0.0^{\mathrm{a}, \mathrm{b}}$ & - & - & - \\
\hline 30 & Nesbyen-Skoglund & $\mathrm{N}$ & - & - & - & -4.4 & 1.4 & 5.8 & - & - & - \\
\hline 31 & Oslo-Blindern & $\mathrm{N}$ & - & - & - & -7.3 & 2.8 & 10.1 & - & - & - \\
\hline 32 & Utsira-Fyr & $\mathrm{N}$ & - & - & - & -19.1 & -4.8 & 14.3 & - & - & - \\
\hline 33 & Vardoe & $\mathrm{N}$ & - & - & - & 3.0 & 8.4 & 5.5 & - & - & - \\
\hline 34 & Kandalaksa & RUS & - & - & - & 1.2 & 0.9 & -0.3 & - & - & - \\
\hline 35 & Kem & RUS & - & - & - & $-6.1^{b}$ & $5.0^{\mathrm{b}}$ & $11.1^{\mathrm{b}}$ & - & - & - \\
\hline 37 & Kostroma & RUS & - & - & - & $-4.3^{\mathrm{b}}$ & $-0.9^{b}$ & $3.3^{\mathrm{b}}$ & - & - & - \\
\hline 40 & Moskow & RUS & - & - & - & $0.5^{\mathrm{b}}$ & $-9.3^{b}$ & $-9.8^{\mathrm{b}}$ & - & - & - \\
\hline 41 & Onega & RUS & - & - & - & -4.9 & 2.3 & 7.2 & - & - & - \\
\hline 42 & Petrozawodsk & RUS & - & - & - & $-5.9^{\mathrm{b}}$ & $2.0^{\mathrm{b}}$ & $7.9^{\mathrm{b}}$ & - & - & - \\
\hline 43 & Pskow & RUS & - & - & - & -7.6 & -1.3 & 6.3 & - & - & - \\
\hline 44 & Sortavala & RUS & - & - & - & -5.6 & -1.9 & 3.7 & - & - & - \\
\hline 46 & Karlstad & $\mathrm{S}$ & - & - & - & -4.8 & -0.2 & 4.5 & - & - & - \\
\hline 47 & Linkoeping & $\mathrm{S}$ & - & - & - & -4.1 & 2.8 & 6.9 & - & - & - \\
\hline 48 & Oestersund & $\mathrm{S}$ & - & - & - & 2.0 & 0.6 & -1.3 & - & - & - \\
\hline
\end{tabular}

See text for definitions of start and end. A few series were included which started later than $1950\left({ }^{\mathrm{a}}\right.$ start year 1954) and ended before $2000\left({ }^{b}\right.$ end year 1999). For a number of stations more than $5 \%$ of the data was missing, so they were excluded from the analyses (station No: 4, 7, 8, 11-13, 17, 36, 38, 39 and 45, see table for station locations). Significant trends (95\% level) in bold.

\subsection{Start}

Between 1901 and 1950 a significant trend in the start of the GS was only found for Koebenhavn, Denmark, with an earlier onset of almost 20 days. Similar tendencies (i.e. not significant trends) of shifts by $>-10-<-20$ days were found at the remaining Danish stations, Stockholm and Uppsala. The remaining stations in the central part of the GBA 
indicated an earlier GS onset as well ( $>0-\leq-10$ days). In the eastern parts, the tendency at Syktyvar, Russia, showed a delay in the GS start of 5.7 days. Between 1951 and 2000, the majority of the stations show tendencies for an earlier GS start of around $>0-\leq-10$ days. Significant trends of ca. 10 days were only found in St Petersburg (Russia) and Vilsandi (Estonia). The largest changes, though not significant, were found in the south-western part of the GBA: Koebenhavn, Vestervig and Norby (Denmark, $-24.5,-22.1$ and -18.1 days respectively) and Utsira Fyr-Faerder Fyr (Norway, -19.1 and -16.6 days respectively). Four stations indicated a delayed (not significant) GS start in this period: Oestersund (Sweden, +2 days), Vardoe (Norway, +3 days) and Moskow and Kandalaksa (Russia, +0.5 and +1.2 days respectively). For the whole 1901 to 2000 period, all available stations showed earlier starts of the GS, and significant trends were found in Koebenhavn, Nordby and Vestervig (Denmark, $-22,8,-18.2$ and -16.5 days respectively), Helsinki (Finland, -9.5 days), St Petersburg (Russia, -10.6 days) and Falun (Sweden, -8.6 days). There were tendencies for earlier GS starts at the remaining stations of $>0-\leq-10$ days.

\subsection{End}

No significant trends in GS end were found in 1901-1950. However, general tendencies towards later GS ends (0.5 to 10 days) at all stations were observed, except in Vestervig and Nordby (Denmark), where tendencies for a shift of 7.3 and 0.8 days respectively to an earlier GS end were found. In the following period (1951-2000) stations close to the North Atlantic, nine of the Russian stations and Karlstad (Sweden) show tendencies for an earlier end of the GS ( $>0-\leq-10$ days), where Elatma and Moskow show earlier GS ends of ca one week. The remaining stations display tendencies for later GS end $(>0-\leq+10$ days). The significant trends in GS end for the 1901 to 2000 period were found around the Baltic Sea (Koebenhavn: +12.6 days, Stockholm: +11.7 days and Helsinki: +10.5 days). Tendencies for later GS ends $(>0-<+10$ days) were found at the remaining stations. In Archangelsk (Russia), there was a significant trend of earlier GS end of 1 week.

\subsection{GSL}

Significant trends in the GSL in 1901-1950 were found in the two eastern Danish stations (Koebenhavn and Hammer-Odde Fyr). These showed increased trends of more than 20 days in the fifty-year period. All other stations close to the Baltic Sea or North Atlantic coasts displayed tendencies for increased GSL of $>0-\leq 10$ days, where the tendencies in Nordby, Stockholm and Uppsala were of $>10-\leq 20$ days. One Russian station (Syktyvar) in the easternmost part of GBA showed a negative tendency for GSL ( -2.7 days). No significant trends were found in 1951-2000, but tendencies show increased GSL in most parts of the GBA of $>0-\leq 20$ days: over 10 days increase in Estonia, Stockholm, Kem (Russia) and the south western part GBA (including a increases of $\geq 20$ days at Nordby and Faerder Fyr in western Norway). In Oestersund (Sweden), Moscou, Kandalaksa and Elatma (Russia), this period displayed a tendency for shorter GSL. There is a clear trend towards and increasing GSL around the Baltic Sea in 1901 to 2000. The significant increases of $>10-\leq 20$ days were found in Stockholm, Uppsala, Helsinki and St Petersburg, and, slightly lower, in Falun (+9.7 days), Hammer-Odde Fyr (+10.5 days, not significant) and Syktyvar (+9.2 days, not significant). Three Danish mainland stations show and even greater trends: +22.6 days in Vestervig, +26.5 days in Nordby and +33.5 days in Koebenhavn. The only tendency for a twentieth century shortening of the GSL was found in Archangelsk in Russia (-3.6 days). 


\subsection{Long-term trends}

When the linear trends of growing season parameters was computed for the longest consecutive period, with less than 5\% missing values, for each record, an increasing growing season is the main feature in the GBA (Table 3). The most prominent changes have occurred in Denmark with increases in GSL of up to 40 days since the late nineteenth century. Significant increases are also observed in central Sweden and St. Petersburg and Kirov in Russia, but not of the same magnitude. The remaining stations that display tendencies for extended GS are in the range of 0.3 to 14.1 days. Only 7 stations out of 49 show tendencies for a shorter GS, but only with a few days ( -1.4 to -9.6 days). More significant changes in GS start (all earlier) were observed than in GS end (all later except Kandalaksa, Russia). Only five stations (out of 48) disclosed tendencies for later GS start (Liepaja, Latvia; Vilnjus, Lithuania; Moscow, Russia; Karlstad and Linkoeping, Sweden). Twenty one (21) stations disclosed earlier GS ends, the majority being Russian stations (17 out of 21 stations), but also one Lithuanian and three Norwegian (two coastal) stations.

\section{Trends in the longest records}

The long-term growing season trends in the three longest records show increases in GSL of 6.2 (Uppsala, 1722-2001, not significant), 8.9 (Stockholm, 1756-2003, significant at $p<0.05$ ) and 22.9 (St. Petersburg, 1805-1999, significant at $p<0.05$ ) days respectively since the eighteenth century (Fig. 3, Table 3). In the Swedish records, the increased GSL was foremost due to significantly delayed GS end (4.6 days in Uppsala and 7.6 days in Stockholm, $p<0.05$ ), since the earlier GS starts were small and not significant in both records. However, at St. Petersburg, earlier GS start of 15.5 days $(p<0.01)$ had greater impact on the large increase in GSL, but still there was an delay of the GS end of one week. The shorter Helsinki record (1828-2001) displayed significant increases in GSL of 31.9 days $(p<0.01)$, where the increase was due to almost equal changes in spring and autumn: an advance of the GS start by 18.0 days $(p<0.01)$ and delayed GS end of 13.8 days $(p<0.01)$. The three longest GS records display high inter-annual and decadal variability, and there are tendencies for increased frequencies of longer growing seasons since the 1950 s.

\section{Discussion}

\subsection{General trends in the GBA}

Unfortunately, the many missing values in the analysed data set make it difficult to evaluate the evolution of GSL within the entire twentieth century over the entire GBA. The reason for the general lack of significant trends in growing season parameters may be attributed to the large inter-annual variability in the records. This is exemplified by the long records in Fig. 3, especially the Stockholm and Uppsala records, where the observed trend is far less important than the yearly and decadal variations. This has also been observed in climatological growing season records for North America (Bootsma 1994; Robeson 2002).

Our results show that, in general, there is a trend in the twentieth century for earlier starts and delayed end, and thus a prolongation, of the GS in the GBA. Averaged over 36 stations in the 1951 to 2000 period, the growing season started 6.3 days earlier, ended 1.1 days later, 
Table 3 Linear trends in growing season parameters over longest consecutive periods with missing values $<5 \%$

\begin{tabular}{|c|c|c|c|c|c|c|}
\hline & & & Trend period & start & end & length \\
\hline 1 & Hammer-Odde-Fyr & DK & $1875-2003$ & -13.6 & 12.9 & 26.5 \\
\hline 2 & Koebenhavn & DK & $1874-2003$ & -22.6 & 18.2 & 40.8 \\
\hline 3 & Nordby & DK & $1875-2003$ & -17.2 & 4.4 & 21.6 \\
\hline 4 & Tranebjerg & DK & $1874-1938$ & -11.5 & 12.8 & 24.4 \\
\hline 5 & Vestervig & DK & 1874-2003 & -19.5 & 12.3 & 31.8 \\
\hline 6 & Helsinki & FIN & $1834-2001$ & -18.0 & 13.8 & 31.9 \\
\hline 7 & Liepaja & LV & 1946-1989 & 2.7 & 10.6 & 7.9 \\
\hline 8 & Vilnjus & LT & 1945-1989 & 7.2 & -0.2 & -7.4 \\
\hline 9 & Archangelsk & RUS & 1883-1999 & -5.6 & -2.0 & 3.6 \\
\hline 10 & Elatma & RUS & 1922-1999 & -7.5 & -7.2 & 0.3 \\
\hline 11 & Gorkij & RUS & 1923-1989 & -13.3 & -4.9 & 8.4 \\
\hline 12 & Kazan & RUS & $1881-1983$ & -5.1 & -2.3 & 2.8 \\
\hline 13 & Kirov & RUS & 1940-1989 & -8.4 & 6.6 & 15.0 \\
\hline 14 & St-Petersburg & RUS & 1805-1999 & -15.5 & 7.5 & 22.9 \\
\hline 15 & Syktyvar & RUS & 1896-1998 & -8.0 & -0.9 & 7.1 \\
\hline 16 & Velikie-Luki & RUS & 1947-1999 & -4.5 & -2.1 & 2.4 \\
\hline 17 & Vytegra & RUS & 1933-1998 & -6.4 & -4.8 & 1.7 \\
\hline 18 & Falun & $\mathrm{S}$ & 1897-2002 & -10.6 & 0.8 & 11.5 \\
\hline 19 & Stensele & $\mathrm{S}$ & $1918-2003$ & -7.6 & 7.8 & 15.4 \\
\hline 20 & Stockholm & $\mathrm{S}$ & $1756-2003$ & -1.4 & 7.6 & 8.9 \\
\hline 21 & Uppsala & $\mathrm{S}$ & $1722-2001$ & -1.6 & 4.6 & 6.2 \\
\hline 22 & Vaexjoe & $\mathrm{S}$ & $1918-2003$ & -3.6 & 4.4 & 8.0 \\
\hline 23 & Vilsandi & EST & 1948-2001 & -8.5 & 2.3 & 10.8 \\
\hline 24 & Voru & EST & 1945-2001 & -6.8 & 5.7 & 12.5 \\
\hline 25 & Jyvaskyla & FIN & $1951-2003$ & -3.0 & 2.7 & 5.8 \\
\hline 26 & Faerder-Fyr & $\mathrm{N}$ & $1951-2003$ & -15.9 & -1.8 & 14.1 \\
\hline 27 & Glomfjord & $\mathrm{N}$ & 1956-2001 & -4.8 & 0.7 & 5.6 \\
\hline 28 & Karasjok & $\mathrm{N}$ & $1951-2001$ & -5.7 & 1.3 & 7.0 \\
\hline 29 & Kjoeremsgrende & $\mathrm{N}$ & 1954-2001 & -3.1 & -2.6 & 0.5 \\
\hline 30 & Nesbyen-Skoglund & $\mathrm{N}$ & 1943-2002 & -0.5 & 1.2 & 1.7 \\
\hline 31 & Oslo-Blindern & $\mathrm{N}$ & 1938-2003 & -0.3 & 1.6 & 1.9 \\
\hline 32 & Utsira-Fyr & $\mathrm{N}$ & $1943-2003$ & -1.4 & -3.7 & -2.2 \\
\hline 33 & Vardoe & $\mathrm{N}$ & $1951-2003$ & -2.6 & 7.7 & 10.3 \\
\hline 34 & Kandalaksa & RUS & $1912-2003$ & -2.6 & -6.7 & -4.1 \\
\hline 35 & Kem & RUS & $1917-2000$ & -5.6 & -1.0 & 4.5 \\
\hline 36 & Kojnas & RUS & $1922-1998$ & -3.2 & -4.6 & -1.4 \\
\hline 37 & Kostroma & RUS & 1925-1999 & -7.8 & -3.3 & 4.6 \\
\hline 38 & Kotlas & RUS & 1936-1999 & -6.3 & -4.3 & 2.0 \\
\hline 39 & Moermansk & RUS & 1938-1998 & -10.3 & -6.0 & 4.3 \\
\hline 40 & Moskow & RUS & 1949-1999 & 0.2 & -9.4 & -9.6 \\
\hline 41 & Onega & RUS & 1936-2002 & -3.1 & -1.2 & 2.0 \\
\hline 42 & Petrozawodsk & RUS & 1945-1999 & -0.3 & 1.1 & 1.4 \\
\hline 43 & Pskow & RUS & $1945-2002$ & -7.5 & 0.9 & 8.3 \\
\hline 44 & Sortavala & RUS & $1945-2000$ & -2.9 & -0.4 & 2.5 \\
\hline 45 & Wologda & RUS & 1939-1998 & -5.2 & -1.9 & 3.3 \\
\hline 46 & Karlstad & $\mathrm{S}$ & 1918-2001 & 5.2 & 2.2 & -3.0 \\
\hline 47 & Linkoeping & $\mathrm{S}$ & $1931-2003$ & 4.9 & 1.7 & -3.1 \\
\hline 48 & Oestersund & $\mathrm{S}$ & 1918-2003 & -3.5 & 0.3 & 3.9 \\
\hline
\end{tabular}

See Fig. 1 for station locations and text for start and end definitions. Bold: significant trends $(p<0.05)$ 

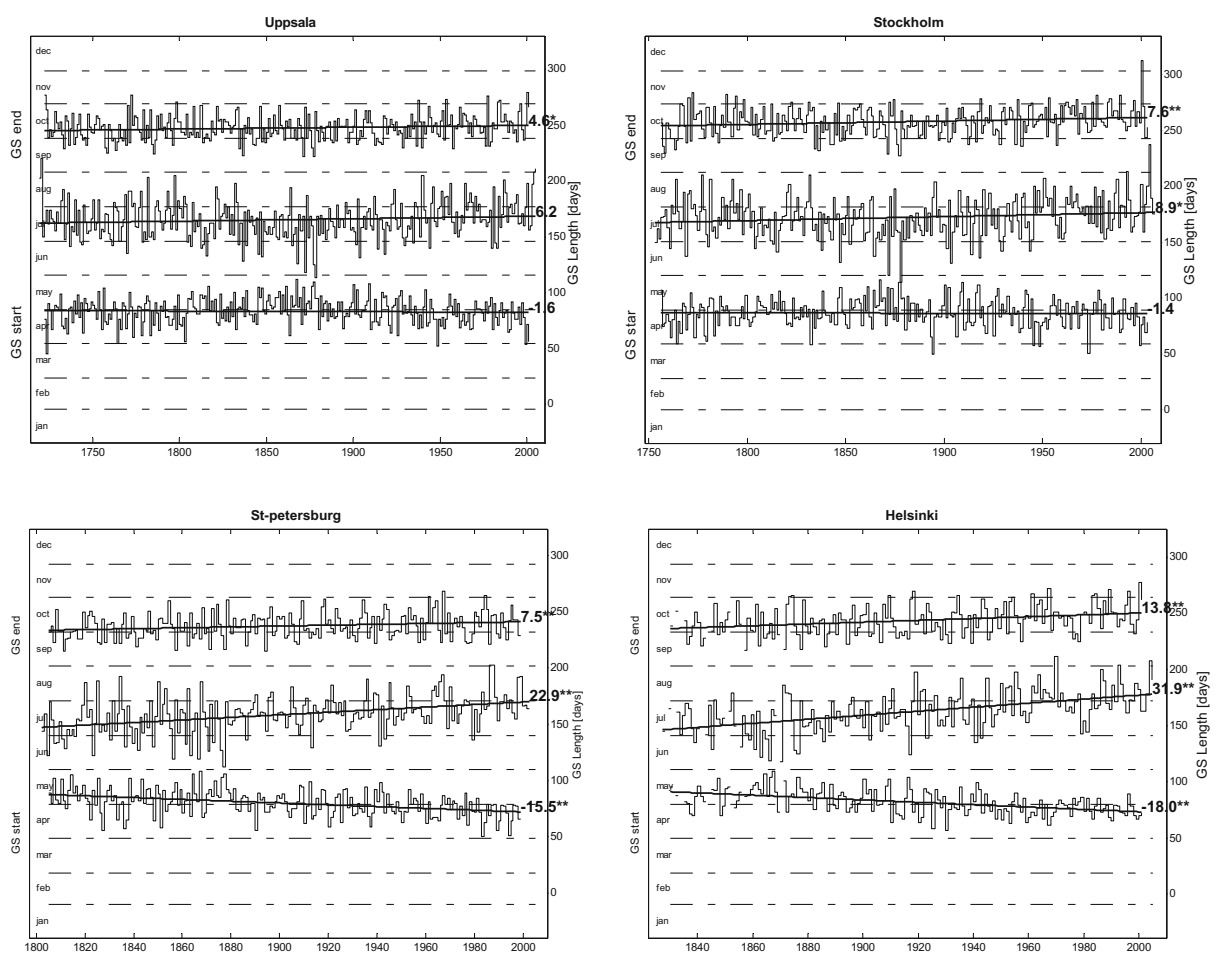

Fig. 3 Trends in growing season start, end and length in the longest records (starting before 1850) in the Greater Baltic Area. Significant trends are indicated by $* p<0.05$ and $* * p<0.01$

yielding an increased GSL of 7.4 days. Consequently, on regional (GBA) scale, the largest changes have occurred in spring, because of warmer temperatures and earlier last frost. Regional changes in autumn are less pronounced, and were only significant for three stations for the 1901-2000 period. Larger changes in spring than autumn in Europe have also been observed in phenological records (e.g. Menzel et al. 2001; Sparks and Menzel 2002). Our results agree well with those obtained for 9 stations in the Nordic region by Carter (1998). He found that the GSL had increased considerably in the past century, between 1 to 3 weeks, but that the lengthening had been less pronounced since the 1960 in most parts. Also, he noted that the absolute magnitude of lengthening showed a declining west-east gradient between Denmark and Finland, and higher inter-annual variability at the western sites. In Germany, Menzel et al. (2003) analysed 41 stations for the 1951-2000 period. The growing season was defined by single-value thresholds of daily minimum and mean air temperatures, and during this 50 -year period they found a lengthening of the growing season of 5.5 to 24.5 days depending on the definition used. The greatest change was found in the frost-free period, due to stronger increase in daily minimum rather than maximum temperatures. Similar results of increased frost-free period were found in Austria, Switzerland (both 25 days) and Estonia (18 days). Furthermore, they noted that the trend was weakening at high-elevation stations ( $>950 \mathrm{~m}$ a.s.1.).

The averaged changes in GBA growing season parameters agree fairly well with previous phenological studies in Europe. Estonian springs had advanced 8 days on average over the 1919-1996 period (Ahas 1999), Dates for phenological phases (e.g., leaf unfolding, flowering and leaf fall), from the International Phenological Gardens, a 
Europe-wide network with a large spatial coverage $\left(42^{\circ} \mathrm{N}-69^{\circ} \mathrm{N}, 10^{\circ} \mathrm{W}-27^{\circ} \mathrm{E}\right)$, showed that from 1959 to 1996, spring events had advanced on average 6.3 days and autumn events had delayed on average by 4.5 days, resulting in an average lengthening of the growing season by 10.8 days (Menzel and Fabian 1999; Menzel 2000). In Germany, phenological data suggested a GSL increased by ca. 9 days over the 1951-96 period, with less changes during autumn than during spring (Menzel et al. 2001).

\subsection{Regional patterns}

Due to the low spatial coverage of station data over the 1901-2000 period, together with a general lack in significant trends in 1951-2000, it is difficult to draw any conclusions about regional patterns. However, the observed tendencies suggest that earlier GS start and extended GSL is a more prominent feature in coastal areas in the southern part of the GBA. Furthermore, the most pronounced changes have occurred in Denmark, where a significant extension of the GSL of 30-40 days was observed. This is in agreement with the findings of Ahas (1999) who, using phenological data, found that spring was advancing more rapidly in coastal regions than in inland areas.

The only station of those covering the entire twentieth century showing a tendency for a shorter GS was Archangelsk, in NW Russia. This station is located close to the Kola Peninsula, where Kozlov and Berlina (2002) examined a number of phenological variables from 1930-1998 and found that snow-melt in spring occurred 16 days later and that the dates of permanent snow cover in the forests began 13 days earlier at the end of the study period than at its beginning. They concluded that the length of the growing season on the Kola Peninsula declined during the past 60 years, due to delayed spring and advanced autumn/winter. However, the station record from Moermansk $(150 \mathrm{~km}$ north of their study area) showed a significant trend towards earlier GS start ( -10.3 days) and despite a tendency for an earlier end of the GS ( -6 days), our data suggests an increase of the GS (4.3 days, not significant) from 1938 to 1998 (Table 3).

The GS pattern during 1951-2000 studied here corresponds to the results of satellite study of GS changes in Fennoscandia, Denmark and the Kola Peninsula by Hogda et al. (2001). Using the GIMMS NDVI dataset for the period 1981 to 1998, they found a delay of spring in the alpine belts and the northern boreal zone, where the strongest delay occurred on the most continental parts of the northern boreal zone. They also noted that spring started earlier in southern Fennoscandia and western Norway. However, their result that the autumn was delayed in the whole area, except for the most continental part of northern Scandinavia, does not agree with our results, where tendencies for earlier GS ends were found at coastal as well as continental stations within the GBA.

On the long term, the longest records show that there is a substantial variability in GS parameters on inter-annual to decadal time scales. In the two Swedish station records from Stockholm and Uppsala, the trend shows an increase in GSL of only around one week in the last 250 years. This is much less that the short-term variability in those records. Furthermore, longer growing seasons need not necessarily be warmer in terms of number of days above a certain temperature threshold. This has previously been shown in Russia and northern Europe by Jones and Briffa (1995) and Jones et al. (2002). Vedin (1990) noted when studying the GS in northernmost Sweden in two 10-year periods, one warm (19311940) and one colder (1979-1988), that GSL was shorter in the warm period than the cold one. Also, examining the relationship between NDVI and tree rings in North America and Eurasia, Kaufmann et al. (2004) suggested that summer temperatures were more important to tree growth than the duration of the GS. 


\subsection{Implications of an extended GS}

Our data suggests that during the period when a significant part of the increase in global temperatures of ca. $0.6^{\circ} \mathrm{C}$ (IPCC 2001), the GS has become on average one week longer in the GBA. Future climate change is projected to increase the length of the growing season even further (e.g. IPCC 2001; ACIA 2004; EEA 2004). Such an increase in GSL, together with a warmer growing season, is expected to advance the potential for crop production at high northern latitudes and increase the potential number of harvests and hence seasonal yields for perennial forage crops (ACIA 2004). Effects in Fennoscandia could be (but see above) elevated tree line and favourable conditions for growing of more southerly fruits (Wielgolaski 2003), and in alpine areas with maximum precipitation during the growing season, lengthening if the growing season as a result of warmer temperatures could lead to improved forest productivity (Hasenauer et al. 1999). However, in climates with distinct seasonality, the vegetation adapts to this seasonality by its phenology, and if a significant climate change occurs, plant species will be less adaptive to this new climate (Kramer et al. 2000). Thus, a rapid climate change, occurring within the next hundred years, could have a large impact on already living trees which would be less adaptive to the prevailing climate. This has been shown in two recent studies, where recent warming has been associated with negative growth responses of trees at treeline sites in Alaska and the central Scandinavian Mountains (Linderholm and Linderholm 2004; Wilmking et al. 2004). Also, if tree species respond differently to climate change, then the competitive relationships between species will alter and hence, in the long run, the species composition of forests and possibly the geographical ranges of species (Kramer et al. 2000).

\section{Conclusions}

This study of trends in growing season parameters from a network of stations in the Greater Baltic Area (GBA), disclosed that, in general, the growing season has been extended in the twentieth century. Averaged for the 1951-2000 period, the GS has become 7 days longer, where most of this change is due to earlier onsets of the GS in spring ( -6 days). However, there are large spatial and temporal differences in GS evolution in the GBA, where the largest changes have occurred in the south western part of the area. Examination of the longest records available, two of them starting in the $1700 \mathrm{~s}$, suggested that over the past 200-250 years, the trend in GSL has been moderate, and that inter-annual to decadal variability is much more pronounced. However, the general tendency towards a longer GS mainly due to an earlier onset was still found for all periods analyzed.

Acknowledgements This work was part of EMULATE (European and North Atlantic daily to Multidecadal climate variability) supported from the European Commission under the Fifth Framework Programme, contract no: EVK2-CT-2002-00161 EMULATE. It was also supported by the Swedish Research Council (VR, grants to Hans Linderholm and Deliang Chen respectively). This paper is contribution No. 4 from TELLUS - The Center for Earth Systems Science at Göteborg University.

\section{References}

Abu-Asab MS, Peterson PM, Shelter SG, Orli SS (2001) Earlier plant flowering in spring as a response to global warming in the Washington, DC, area. Biodivers Conserv 10:597-612

ACIA (2004) Impacts of a warming Arctic: arctic climate impact assessment. Cambridge University Press, Cambridge, UK, p 140 
Ahas R (1999) Long-term phyto-, ornitho- and ichthyophenological time-series analyses in Estonia. Int J Biometeorol 42:119-123

Ahas R, Aasa A, Menzel A, Fedotova VG, Scheifinger H (2002) Changes in European spring phenology. Int J Climatol 22:1727-1738

Ahas A, Jaagus J, Ahas R, Sepp M (2004) The influence of atmospheric circulation on plant phenological phases in central and eastern Europe. Int J Climatol 24:1551-1564

Barford CC, Wofsy SC, Goulden ML, Munger JW, Pyle EH, Ubranski SP, Hutyra L, saleska SR, Fitzjarrald D, Moore K (2001) Factors controlling long- and short-term sequestration of atmospheric CO2 in a midlatitude forest. Science 294:1688-1691

Bergström H, Moberg A (2002) Daily air temperature and pressure series for Uppsala (1722-1998). Clim Change 53:213-252

Bootsma A (1994) Long term (100 yr) climate trends for agriculture at selected locations in Canada. Clim Change 26:65-88

Carter TR (1998) Changes in the thermal growing season in Nordic countries during the past century and prospects for the future. Agric Food Sci Finl 7:161-179

Cayan DR, Kammerdiener SA, Dettinger MD, Caprio JM, Peterson DH (2001) Changes in the onset of spring in the western United States. Bull Am Meteorol Soc 82:399-415

Chmielewski F-M, Rötzer T (2001) response to phenology to climate change across Europe. Agric For Meteorol 108:101-112

Chmielewski F-M, Rötzer T (2002) Annual and spatial variability of the beginning of growing season in Europe in relation to air temperature changes. Clim Res 19:257-264

Chmielewski F-M, Müller A, Bruns E (2004) Climate changes and trends in phenology of fruit trees and field crops in Germany, 1961-2000. Agric For Meteorol 121:69-78

D'Odorico P, Yoo J-C, Jaeger S (2002) Changing seasons: an effect of the North Atlantic Oscillation. J Climate 15:435-445

EEA (2004) Impacts of Europe's changing climate - an indicator based assessment. European Environment Agency report no 2/2004, p 107

Frich P, Alexander LV, Della-Marta P, Gleason B, Haylock M, Klein Tank AMG, Peterson T (2002) Observed coherent changes in climatic extremes during the second half of the twentieth century. Clim Res 19:193-212

Hasenauer H, Nemani RR, Schadauer K, Running SW (1999) Forest growth response to changing climate between 1961 and 1990 in Austria. For Ecol Manag 122:209-219

Heino R (1994) Climate in Finland during the period of meteorological observations. Finnish Meteorological Institute Contributions, No. 12, Finnish Meteorological Institute, p 209

Hogda KA, Karlsen SR, Solheim I (2001) Climatic change impact on growing season in Fennoscandia studied by a time series of NOAA AVHRR NDVI data. Proceedings of IGARSS. 9-13 July 2001, Sydney, Australia. ISBN 0-7803-7033-3

Hughes L (2000) Biological consequences of global warming: is the signal already apparent. Trends in Ecological Evolution 15:56-61

IPCC (2001) Climate change 2001: the scientific basis. Contribution of working group I to the third assessment report of the international panel on climate change. In: Houghton JT, Ding Y, Griggs DJ, Noguer M, van der Linden PJ, Dai X, Manskell K, Johnson CA (eds). Cambridge University Press, Cambridge, United Kingdom and New York, NY, USA, p 881

Jones PD, Briffa KR (1995) Growing season temperatures over the former Soviet Union. Int J Climatol 15:943-959

Jones PD, Lister DH (2002) The daily temperature record for St. Petersburg. Clim Change 53:253-267

Jones PD, Briffa KR, Osborn TJ, Moberg A, Bergström H (2002) Relationships between circulation strength and the variability of growing-season and cold-season climate in northern and central Europe. The Holocene 12:643-656

Juday GP, Barber V, Duffy P, Linderholm H, Rupp S, Sparrow S, Vaganov E, Yarie J, Berg E, D’Arrigo R, Eggertsson O, Furyaev VV, Hogg EH, Huttunen S, Jacoby G, Kaplunov VY, Kellomaki S, Kirdyanov AV, Lewis CE, Linder S, Naurzbaev MM, Pleshikov FI, Runesson UT, Savva YV, Sidorova OV, Stakanov VD, Tchebakova NM, Valendik EN, Vedrova EF, Wilmking M (2005) The Arctic climate impact assessment- the scientific report, Chapter 14: forests, land management and agriculture. Cambridge University Press, Cambridge, UK, pp 781-862

Kaufmann RK, D’Arrigo RD, Laskowski C, Myneni RB, Zhou L, Davi NK (2004) The effects of growing season and summer greenness on northern forests. Geophys Res Lett 31:L09205

Keeling CD, Chin JFS, Whorf TP (1996) Increased activity of northern vegetation inferred from atmospheric $\mathrm{CO}_{2}$ measurements. Nature 382:146-149

Klein Tank AMG et al (2002) Daily dataset of 20th-century surface air temperature and precipitation series for the European Climate Assessment. Int J of Climatol 22:1441-1453 
Kozlov MV, Berlina NG (2002) Decline in length of the summer season on the Kola Peninsula, Russia. Clim Change 54:387-398

Kramer K, Leinonen I, Loustau D (2000) The importance of phenology for the evaluation of impact of climate change on growth of boreal, temperate and Mediterranean forests ecosystems: an overview. Int J Biometeorol 44:67-75

Linderholm HW, Linderholm K (2004) Age-dependent climate sensitivity of Pinus sylvestris L. in the central Scandinavian Mountains. Boreal Environ Res 9:307-317

Menzel A (2000) Trends in phenological phases in Europe between 1951 and 1996. Int J Biometeorol 44:76-81

Menzel A (2003) Phenological anomalies in Germany and their relation to air temperature and NAO. Clim Change 57:243-263

Menzel A, Fabian P (1999) Growing season extended in Europe. Nature 397:659

Menzel A, Estrella N, Fabian P (2001) Spatial and temporal variability of the phenological seasons in Germany from 1951-1996. Glob Chang Biol 7:657-666

Menzel A, Jakobi G, Ahas R, Scheifinger H, Estrella N (2003) Variations of the climatological growing season (1951-2000) in Germany compared with other countries. Int J Climatol 23:793-812

Moberg A, Bergström H, Ruiz Krigsman J, Svanered O (2002) Daily air temperature and pressure series for Stockholm (1756-1998). Clim Change 53:171-212

Moberg A, Jones PD, Lister D, Walther A, Brunet M, Jacobeit J, Saladie O, Sigro J, Aguilar E, Della-Marta P, Luterbacher J, Yiou P, Alexander LV, Chen D, Klein Tank AMG, Alexandersson H, Almarza C, Auer I, Barriendos M, Begert M, Bergström H, Böhm R, Butler J, Caesar J, Drebs1 A, Founda1 D, Gerstengarbe F-W, Giusi M, Jónsson T, Maugeri M, Österle H, Pandzic K, Petrakis M, Srnec L, Tolasz R, Tuomenvirta H, Werner PC, Linderholm H, Philipp A, Wanner H, Xoplaki E (2006) Indices for daily temperature and precipitation extremes in Europe analyzed for the period 1901-2000. J Geophys Res 111:D22106, doi:10.1029/2006JD007103

Myneni RC, Keeling CD, Tucker CJ, Asrar G, Nemani RR (1997) Increased plant growth in the northern high latitudes from 1981 to 1991 . Nature 386:698-702

Parmesan C, Yohe G (2003) A globally coherent fingerprint of climate change impacts across natural systems. Nature 421:37-42

Peñuelas J, Filella I (2001) Responses to a warming world. Science 294:793-794

Peñuelas J, Filella I, Comas P (2002) Changed plant and animal life cycles from 1952 to 2000 in the Mediterranean region. Glob Chang Biol 8:531-544

Robeson SM (2002) Increasing growing-season length in Illinois during the 20th century. Clim Change 52:219-238

Root TL, Price JT, Hall KR, Schneider SH, Rosenzweig C, Pounds JA (2003) Fingerprints of global warming on wild animals and plants. Nature 421:57-60

Scheifinger H, Menzel A, Koch E, Peter C, Ahas R (2002) Atmospheric mechanisms governing the spatial and temporal variability of phenological phases in central Europe. Int J Climatol 22:1739-1755

Scheifinger H, Menzel A, Koch E, Peter C (2003) Trends of spring time frost events and phenological dates in Central Europe. Theor Appl Climatol 74:41-51

Schwartz MD (1999) advancing to full bloom: planning phenological research for the 21 st century. Int J Biometeorol 42:113-118

Schwartz MD, Chen X (2002) Examining the onset of spring in China. Clim Res 21:157-164

Skaggs RH, Baker DG (1985) Fluctuations in the length of the growing season in Minnesota. Clim Change 7:403-414

Sparks T, Menzel A (2002) Observed changes in seasons: an overview. Int J Climatol 22:1715-1725

Vedin H (1990) Frequency of rare weather events during periods of extreme climate. Geografiska Annaler $72 \mathrm{~A}: 151-155$

Walther A, Linderholm HW (2006) A comparison of growing season indices for the Greater Baltic Area. Int J Biometeorol 51:107-118, doi:10.1007/s00484-006-0048-5

White MA, Running SW, Thornton PE (1999) The impact of growing-season length variability on carbon assimilation and evapotranspiration over 88 years in the eastern US deciduous forest. Int J Biometeorol 42:139-145

Wielgolaski F-E (2003) Climatic factors governing plant phenological phases along a Norwegian fjord. Int J Biometeorol 47:213-220

Wilmking M, Juday GP, Barber VA, Zald HSJ (2004) Recent climate warming forces contrasting growth responses of white spruce at treeline in Alaska through temperature thresholds. Glob Chang Biol 10:1742-1736

Yue S, Pilon P, Cavadias G (2002) Power of the Mann-Kendall and Spearman's rho tests for detecting monotonous trends in hydrological series. J Hydrol 259:254-271 